\title{
Atmospheric Bulk Deposition of Polychlorinated Dibenzo- $p$-Dioxins, Dibenzofurans, and Polychlorinated Biphenyls in Finland
}

\author{
Markku Korhonen ${ }^{1, *}$, Matti Verta ${ }^{1}$, Simo Salo ${ }^{1}$, Jussi Vuorenmaa ${ }^{1}$, Hannu Kiviranta ${ }^{2}$ \\ and Päivi Ruokojärvi ${ }^{2}$ \\ 1 Finnish Environment Institute, P.O. Box 140 Helsinki, Finland; matti.verta@ymparisto.fi (M.V.); \\ simo.salo@ymparisto.fi (S.S.); jussi.vuorenmaa@ymparisto.fi (J.V.) \\ 2 National Institute for Health and Welfare, Department of Health Protection, Chemicals and Health Unit, \\ P.O. Box 95 Kuopio, Finland; hannu.kiviranta@thl.fi (H.K.); paivi.ruokojarvi@thl.fi (P.R.) \\ * Correspondence: Markku.Korhonen@ymparisto.fi; Tel.: +358-29-5251268
}

Academic Editor: Boris Peter Koch

Received: 17 March 2016; Accepted: 23 August 2016; Published: 7 September 2016

\begin{abstract}
The deposition of polychlorinated dibenzo- $p$-dioxins, dibenzofurans (PCDD/Fs), and polychlorinated biphenyls (PCBs) was studied during the period 2006-2008 in northern Finland (Pallas), 1998-2008 in southern Finland (Evo) and 2002-2004 in the Gulf of Finland archipelago (Utö). Retrospective snow samples were taken from the whole snowbank in Evo in 2003 and 2004, and recently fallen snow was collected in Evo in 2006-2008. The concentrations of PCDD/Fs in the depositions were usually small. The limit of quantification (LOQ) was often reached in Pallas and Utö. The analysis results of PCDD/F and PCB congeners from Evo were used to predict numerical results with linear regression for those congeners with results below LOQ. The deposition of PCDD/Fs in Pallas was mostly less than $0.4 \mathrm{pg} \cdot \mathrm{m}^{-2} \cdot$ day $^{-1}$ WHO-TEQ and less than $1.0 \mathrm{pg} \cdot \mathrm{m}^{-2} \cdot$ day $^{-1}$ WHO-TEQ and $0.5 \mathrm{pg} \cdot \mathrm{m}^{-2} \cdot$ day $^{-1}$ WHO-TEQ in Evo and Utö, respectively. The deposition of co-planar PCBs (cPCBs) was between 0.01 and $0.1 \mathrm{pg} \cdot \mathrm{m}^{-2}$. day ${ }^{-1}$ WHO-TEQ. Annual PCDD/F deposition, calculated from the amount of collected rain and chemical analysis results, varied in Pallas between 0.04 and $0.15 \mathrm{ng} \cdot \mathrm{m}^{-2} \cdot$ year $^{-1}$ WHO-TEQ, in Evo between 0.11 and $0.22 \mathrm{ng} \cdot \mathrm{m}^{-2} \cdot$ year $^{-1}$ WHO-TEQ and in Utö between 50 and $145 \mathrm{pg} \cdot \mathrm{m}^{-2} \cdot \mathrm{year}^{-1}$ WHO-TEQ. For CPCBs the annual deposition in Pallas was 2-11 pg. $\mathrm{m}^{-2} \cdot$ year $^{-1} \mathrm{WHO}-\mathrm{TEQ}$, in Evo 6-17 pg. $\mathrm{m}^{-2} \cdot \mathrm{year}^{-1} \mathrm{WHO}$-TEQ and in Utö 4-8 pg. $\mathrm{m}^{-2}$.year ${ }^{-1}$ WHO-TEQ. Wind directions are considered to be the main reason for the variation between seasons. Congener 1,2,3,7,8-PeCDD dominated in Pallas, Evo, and Utö, being $35 \%$, 48\%, and $47 \%$ of the overall WHO-TEQ, followed by 2,3,4,7,8-PeCDF (about 10\%). The calculated $\mathrm{pg} / \mathrm{L}$ concentrations of 1,2,3,7,8-PeCDD were about the same level as 2,3,4,7,8-PeCDF, but the TEF correlations being twice as big ensured that all WHO-TEQ contributions were bigger. PCB126 accounted for 30\% of WHO-TEQ in Pallas, whereas in Evo and Utö the proportion was less than $5 \%$. Of PCDD/F homology groups, the highest concentration was found in Pallas as OCDDs (55\%), followed by Evo and Utö, at $42 \%$ and $38 \%$, respectively. Decreasing temporal PCDD/F deposition trends were observed for highly chlorinated octa-, hepta-, and hexacongeners. The findings indicate that, regardless of the major importance of Kymijoki to the dioxins in the Gulf of Finland, deposition sources may contribute more to the PCDD/Fs' intake of fish in the studied sea area.
\end{abstract}

Keywords: deposition; PCDDs; PCDFs; PCBs; Finland

\section{Introduction}

Rather than produced intentionally, PCDD/Fs are minor impurities found in several chlorinated chemicals. Historically, the largest emission source categories in Europe are the incineration of 
municipal, hospital, and hazardous waste and sewage sludge. The originating of PCDD/Fs in incineration processes is clarified in new reports and also the methods to reduce the formation of PCDD/Fs are investigated [1,2]. The second largest are combustion sources. The third largest are industrial sources, like iron ore sintering which these days is believed to be the most important single emission source type [3], with the fourth largest being reservoir sources, or accidental and miscellaneous sources [4-7]. According to official emissions reports to the European Monitoring and Evaluating Programme (EMEP), the main emission sectors in Finland are combustion in power plants and industry, industrial processes, transport, commercial and residential combustion, and other stationary combustion $[8,9]$. At the global level, the initial distribution of dioxin emissions suggested several areas of likely high local dioxin production due to higher levels of economic activity [10].

PCBs have mainly been used by the power industry in electrical transformers, capacitors and hydraulic equipment, and as lubricants. PCBs have also been added to many products used directly by industry, such as adhesives, waxes, and links [11]. Since the mid-1970s, PCBs have been removed from active use in most countries. Dioxin-like PCBs usually constitute a small fraction of PCB mixtures. Dioxin-like PCB sources include the use and disposal of industrial PCB products or by-products of municipal solid waste incineration [12].

$\mathrm{PCDD} / \mathrm{Fs}$ are either absorbed in particulate matter or present in the vapor phase. PCDD/Fs can also undergo association with aerosols as they are transported in the air $[13,14]$. Highly chlorinated dioxin/furans dominate the particle phase, while lower chlorinated dioxin/furans dominate the gas phase $[15,16]$. Dioxins' atmospheric travel distance depends on their gas/particle partitioning and particle size distribution for particulate dioxins and furans and the deposition characteristics of the gaseous and particulate PCDD/Fs congeners [17]. Atmospheric deposition depends on precipitation, atmospheric turbulence, and the height of the emission and deposition surface type [16]. It has been reported that about 76\% of the total deposition of PCDD/Fs (WHO-TEQ) to the Great Lakes is absorbed into organic matter in aerosols. More than $92 \%$ of all the deposition is particulate phase wet deposition and only $5 \%-8 \%$ is particle phase dry deposition [18]. Wet particle deposition was reported to contribute $30 \%-90 \%$ of the total deposition in different congeners with mass balance modelling [19].

In the EMEP region, using the modelled emission data of PCDD/Fs, significant levels in deposition can be seen mainly in Eastern Europe [20]. According to measured atmospheric particle-bound and gaseous PCDD/Fs concentrations in the air in southern Sweden, the highest levels were found in air that had passed over the European continent. In air that had passed over the British Isles and air from northerly directions, the concentrations were low [14].

Studying the surface snow in Antarctica, only 1,2,3,4,6,7,8-HpCDD and OCDD were detected among 17 priority PCDD/Fs in two samples [21]. However, a few results were published in the Nordic countries [14,22-25]. In addition, few results have been published with regard to long-term monitoring and all toxic dioxins and PCBs. In this study, we summarize the monitoring results of PCDD/F and PCB concentrations in depositions in Finland between 1998 and 2008. We also calculate the bulk deposition as WHO-TEQ $\mathrm{pg} \cdot \mathrm{m}^{-2} \cdot \mathrm{day}^{-1}$, compare our results with other studies and make rough estimates for the northern Baltic Sea.

\section{Material and Methods}

\subsection{Sampling}

Monthly bulk deposition was collected at three stations during the snow-free period (May-November/December) at Evo (1998-2008), Utö (2002-2004), and Pallas (2006-2008) (Figure 1). Additional snow samples were collected in Evo from the total snowpack gathered during late winter in March 2003 and 2004, and a sampling also in winter recently fallen snow at Evo was carried out in 2006-2008. Evo is located about $100 \mathrm{~km}$ inland from the coast of the Gulf of Finland, with a distance of some $40-60 \mathrm{~km}$ from the nearest large urban areas. The Evo region is a mostly forested and agricultural area. Pallas is situated in the subarctic region of northern Finland, with a small urban area 
$35 \mathrm{~km}$ away. The nearest larger urban areas are situated $100 \mathrm{~km}$ and $200 \mathrm{~km}$ away, respectively. Utö is a small island some $70 \mathrm{~km}$ off the south-west coast near the open Baltic Proper. The distance between the southernmost and northernmost stations is some $1000 \mathrm{~km}$.

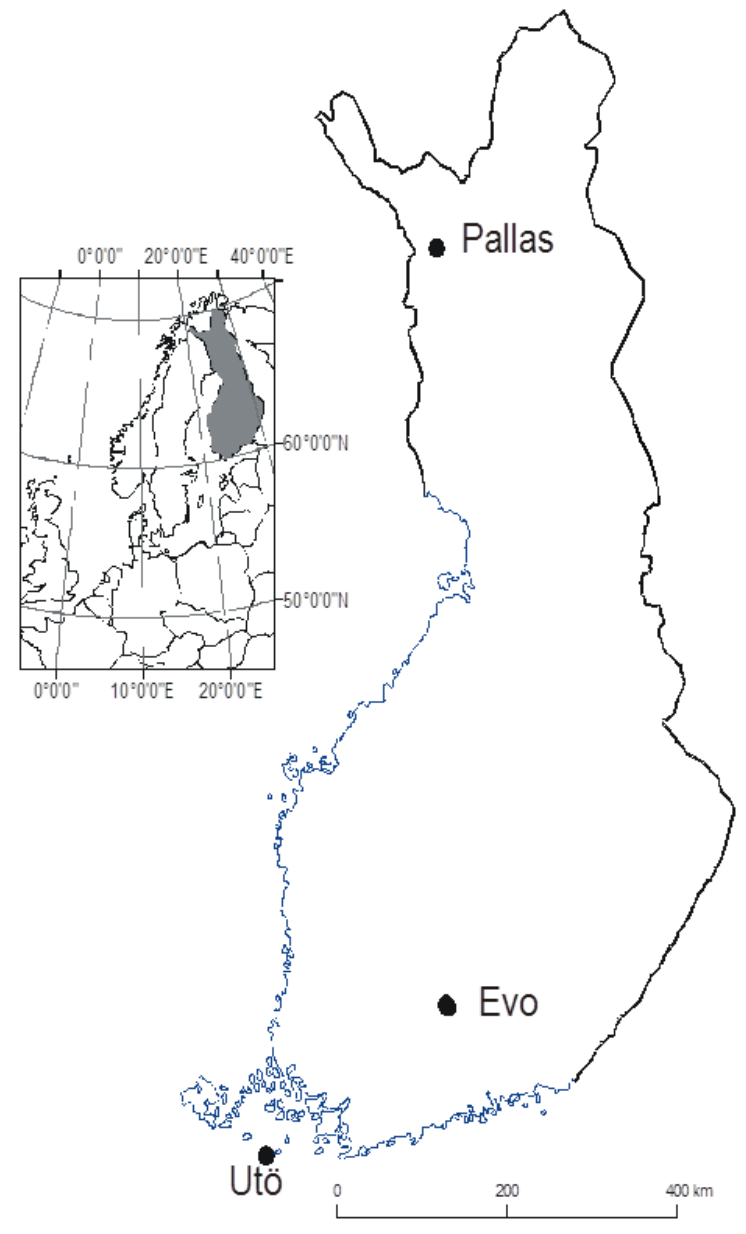

Figure 1. The map of Finland and the regions of Pallas, Evo, and Utö.

\subsection{Sample Extraction and Clean-up}

The bulk deposition (wet deposition and dry particles) sampling was performed with two glass funnels (30 cm in diameter), which were installed $120 \mathrm{~cm}$ above the ground in an open place in a forest (Evo, Pallas) and on open bedrock in Utö. The samples were collected through funnels into 5-liter glass (Pyrex) bottles using a PTFE tube $(14 \mathrm{~mm})$. The bottles were buried in the ground and covered with a ten-centimeter-thick styrox plate to avoid photodegradation and heating of the sun. To avoid evaporation, $100 \mathrm{~mL}$ of dichloro-methane (Merck n:o 6054) and $100 \mathrm{~mL}$ of deionized water (purity class $=1$, conductivity $<0.005 \mathrm{mS} \cdot \mathrm{m}^{-1}$ ) were added to the bottles prior to sampling. The sampling period ranged between 4 and 5 weeks. Before the start of each sampling period, the bottles, funnels and tubes were carefully washed with ethyl alcohol and deionized water. The method used was a bulk sampler modified by DMU, the National Environmental Research Institute, Denmark [26]. Bulk deposition sampling methods have been widely used in several studies [27-32].

The intercomparisons and quality control of sampling methods for deposition measurements of organic compounds had been evaluated in a joint project under the Nordic Council of Ministers [33].

The retrospective snow samples in 2003 and 2004 were taken using polyvinyl tubes, which were (diameter $10 \mathrm{~cm}$ and length $50 \mathrm{~cm}$ ) by placing them through the snowpack. Any collection of vegetation or litter was carefully avoided. The wintertime deposition was collected with a bulk sampler with a surface area of $0.8 \mathrm{~m}^{2}$ connected with a PTFE-coated funnel to a Teflon bottle and melted after 
one month's collection in a clean room. Sampling in bottles and washing procedures were equal to that in wet and dry sampling.

\subsection{Instrumental Analyses}

For the PCDD/Fs and PCBs analyses, the water samples were extracted with hexane and sodium chloride in glass funnels. Extracts were dried with activated $\mathrm{Na}_{2} \mathrm{SO}_{4}$ before fractionation and purification. The extracts were fractionated and purified by eluting them through three columns consisting of (1) sodium sulphate and silica gel; (2) activated carbon and Celite; and (3) aluminium oxide. The quantification of PCDD/Fs and CPCBs was achieved by measuring the native compounds and ${ }^{13} \mathrm{C}$-labeled internal standards using high-resolution gas chromatography-mass spectrometry (VG70SE or Autospec Ultima; Micromass, Manchester, UK).

\subsection{Calculations}

The PCDD/F concentrations in bulk deposition (pg. $\mathrm{L}^{-1}$ ) and the amount of deposition for a day $\left(\mathrm{pg} \cdot \mathrm{m}^{-2} \cdot\right.$ day $\left.^{-1}\right)$ or a year $\left(\mathrm{ng} \cdot \mathrm{m}^{-2} \cdot \mathrm{year}^{-1}\right)$ were calculated. We used the PCDD/Fs and CPCBs analyses results from Evo in linear regression equations between different congeners to predict numerical results for the congeners with analytical results below LOQ. The best possible surrogates of these congeners were calculated using Pearson correlation, 16 PCDD/F congeners or homolog concentrations, and $21 \mathrm{cPCBs}$ equations were used to predict $24 \mathrm{PCDD} /$ Fs congeners and $33 \mathrm{cPCB}$ congeners together in all the study areas (Figure 2). The model was verified by the analysis results from the same congeners that were modelled. The percentages of the predicted results were calculated from these analyses results. In addition, with the calculation of WHO-TEQ [34], values were used equally. In Utö the amount of PCBs under the LOQ was 112 from 120 analyses and 93 from 105 analyses, respectively, and these results were not used. In calculations for the annual deposition amount, missing concentration values were replaced by the mean of the year and the precipitation of the actual month was used.

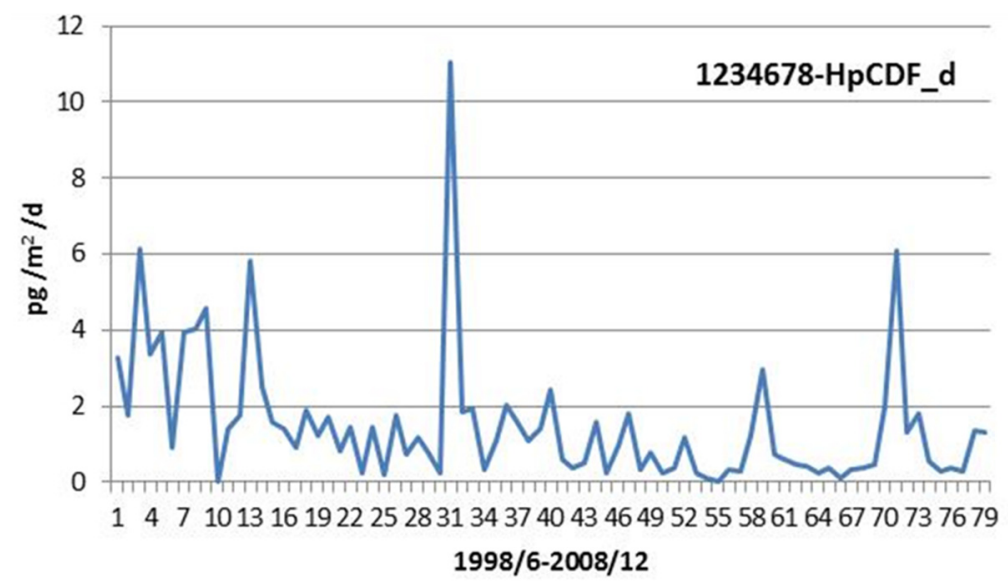

Figure 2. Visual Basic program for multivariate Mann-Kendall tests of monotone trends in time series of data grouped by sites, plots, and seasons, to evaluate the possible trends using Evo results, was used and the trend of $1,2,3,4,6,7,8-\mathrm{HpCDF} \mathrm{pg} \cdot \mathrm{m}^{-2} \cdot$ day $^{-1}$ are presented in these figures.

We evaluated the possible temporal trends in Evo by using the Visual Basic program for multivariate Mann-Kendall tests of monotone trends in time series of data grouped by sites, plots, and seasons, developed by Anders Grimvall at the Swedish University of Agricultural Sciences. The reason for choosing this program was its sensitivity to regression. Because of the sample collection system, generally only one result for one month was available. In case more data existed, mean values were used. We used the $\mathrm{pg} \cdot \mathrm{L}^{-1}$ and $\mathrm{pg} \cdot \mathrm{m}^{-2} \cdot \mathrm{day}^{-1}$ results for all toxic and sum values 
of PCDD/Fs (17 and 8, respectively) and non-ortho PCBs [35]. In total, 58 trends were calculated (Supplementary Materials Table S1).

\section{Results}

\subsection{PCDD/F and PCB Concentrations and Congener Profiles}

The highest concentrations of PCDDs and PCDFs were measured in Evo (mean of the sum of all congeners $4.12 \mathrm{pg} \cdot \mathrm{L}^{-1}$ and $3.11 \mathrm{pg} \cdot \mathrm{L}^{-1}$ respectively) and the lowest in Pallas (1.61 $\mathrm{pg} \cdot \mathrm{L}^{-1}$ and $0.65 \mathrm{pg} \cdot \mathrm{L}^{-1}$ ) (Table 1). OCDD was clearly dominant from all PCDDs in all areas followed by 1,2,3,4,6,7,8-HpCDD. OCDF and 1,2,3,4,6,7,8-HpCDF dominated the furans and less variation between different congeners was evident. The congener pattern varied between sites. While sum PCDDs and PCDFs were almost equal in the two southern stations, PCDDs dominated over PCDFs in Pallas, the northernmost station.

In the sum concentrations of PCBs, there was no clear difference between the sites. The sum concentrations of mono-ortho PCBs and indic7 PCBs in Pallas and Evo were about 10 times and 100 times as big, respectively, than the amount of non-ortho PCBs. In any case, PCB 77 was clearly dominant in all areas in non-ortho PCBs.

Table 1. Concentrations (mean and standard deviations, SD) of PCDD/Fs and PCBs (pg/L) in Pallas, Evo, and Utö.

\begin{tabular}{ccccccc}
\hline Congener & \multicolumn{2}{c}{ PALLAS } & \multicolumn{2}{c}{ EVO } & \multicolumn{2}{c}{ UTÖ } \\
\hline & Mean & SD & Mean & SD & Mean & SD \\
\hline PCDDs & & & & & & \\
\hline 2378-TCDD & 0.02 & 0.03 & 0.04 & 0.04 & 0.01 & 0.01 \\
12378-PeCDD & 0.06 & 0.08 & 0.18 & 0.44 & 0.08 & 0.08 \\
123478-HxCDD & 0.01 & 0.02 & 0.06 & 0.09 & 0.04 & 0.05 \\
123678-HxCDD & 0.05 & 0.05 & 0.24 & 0.69 & 0.18 & 0.16 \\
123789-HxCDD & 0.04 & 0.03 & 0.23 & 0.48 & 0.09 & 0.08 \\
1234678-HpCDD & 0.3 & 0.38 & 1.1 & 1.99 & 0.53 & 0.63 \\
OCDD & 1.13 & 1.72 & 2.28 & 1.96 & 1.29 & 1.26 \\
sum PCDDs & 1.61 & 2.3 & 4.12 & 5.7 & 2.23 & 2.28 \\
\hline PCDFs & & & & & & \\
\hline 2378-TCDF & 0.02 & 0.01 & 0.11 & 0.09 & 0.09 & 0.07 \\
12378-PeCDF & 0.02 & 0.01 & 0.12 & 0.11 & 0.08 & 0.12 \\
23478-PeCDF & 0.03 & 0.03 & 0.18 & 0.2 & 0.21 & 0.23 \\
123478-HxCDF & 0.04 & 0.02 & 0.23 & 0.3 & 0.21 & 0.23 \\
123678-HxCDF & 0.04 & 0.02 & 0.17 & 0.19 & 0.24 & 0.23 \\
234678-HxCDF & 0.04 & 0.03 & 0.21 & 0.25 & 0.26 & 0.24 \\
123789-HxCDF & 0.02 & 0.01 & 0.05 & 0.04 & 0.02 & 0.04 \\
1234678-HpCDF & 0.16 & 0.11 & 0.77 & 0.86 & 0.68 & 0.87 \\
1234789-HpCDF & 0.06 & 0.03 & 0.31 & 0.95 & 0.1 & 0.1 \\
OCDF & 0.21 & 0.14 & 0.95 & 1.62 & 0.7 & 0.56 \\
sumPCDFs & 0.65 & 0.42 & 3.11 & 4.62 & 2.57 & 2.69 \\
\hline non-ortho & & & & & & \\
\hline PCB 81 & 0.09 & 0.12 & 0.1 & 0.1 & 0.1 & 0.05 \\
PCB 77 & 2.27 & 2.91 & 1.58 & 1.61 & 1.77 & 0.82 \\
PCB 126 & 0.13 & 0.16 & 0.13 & 0.08 & 0.14 & 0.08 \\
PCB 169 & 0.02 & 0.01 & 0.04 & 0.03 & 0.05 & 0.03 \\
sum non-ortho & 2.52 & 3.21 & 1.85 & 1.82 & 2.05 & 0.98 \\
\hline & & & & & &
\end{tabular}


Table 1. Cont.

\begin{tabular}{ccccccc}
\hline Congener & \multicolumn{2}{c}{ PALLAS } & \multicolumn{2}{c}{ EVO } & UTÖ \\
\hline & Mean & SD & Mean & SD & Mean & SD \\
\hline mono-ortho & & & & & & \\
\hline PCB 123 & 1.38 & 1.55 & 1.43 & 1.04 & & \\
PCB 118 & 7.02 & 4.89 & 8.97 & 5.21 & & \\
PCB 114 & 0.62 & 0.85 & 0.34 & 0.53 & \\
PCB 105 & 2.64 & 1.87 & 3.63 & 1.93 & \\
PCB 167 & 2.79 & 3.78 & 2 & 1.82 & \\
PCB 156 & 1.16 & 1 & 2.19 & 1.79 & \\
PCB 157 & 0.77 & 0.7 & 0.93 & 0.72 & \\
PCB 189 & 0.92 & 1.04 & 1.02 & 0.87 & \\
sum mono-ortho & 17.3 & 15.68 & 20.51 & 13.92 & \\
\hline indic 7 & \multicolumn{7}{c}{} & & \\
PCB 28 /31 & 102.83 & 105.02 & 62.53 & 71.38 & & \\
PCB 52 & 23.82 & 34.73 & 26.04 & 25.24 & & \\
PCB 101 & 31.18 & 57.05 & 32.11 & 74.05 & & \\
PCB 118 & 7.02 & 4.89 & 8.97 & 5.21 & & \\
PCB 153 & 77.79 & 99.53 & 84.52 & 108.33 & & \\
PCB 138 & 14.24 & 9.85 & 50.96 & 74.97 & \\
PCB 180 & 7.29 & 3.86 & 20.17 & 33.31 & \\
sum indic 7 & 264.18 & 314.93 & 285.3 & 392.49 & \\
\hline
\end{tabular}

\section{2. $P C D D / F$ and $C P C B$ Deposition}

The deposition of PCDD/Fs in Pallas was mainly less than $0.4 \mathrm{pg} \cdot \mathrm{m}^{-2} \cdot \mathrm{day}^{-1} \mathrm{WHO}$-TEQ and less than $1.0 \mathrm{pg} \cdot \mathrm{m}^{-2} \cdot$ day $^{-1}$ WHO-TEQ and $0.5 \mathrm{pg} \cdot \mathrm{m}^{-2} \cdot$ day $^{-1}$ WHO-TEQ in Evo and Utö, respectively. The deposition of cPCBs was between 0.01 and $0.1 \mathrm{pg} \cdot \mathrm{m}^{-2} \cdot$ day $^{-1}$ WHO-TEQ. Similarly to concentrations, the deposition of PCDD/Fs was highest in Evo, clearly lower in Utö and lowest in Pallas. For PCB no clear difference was found between the sites (Tables 2 and 3). There were two exceptionally high PCDD/F deposition rates in Evo $\left(12\right.$ and $10 \mathrm{pg} \cdot \mathrm{m}^{-2} \cdot$ day $\left.^{-1}\right)$ in October 1999 and August 2000 which strongly affected the mean deposition rates for these years. Both these peaks were mainly caused by congener 1,2,3,7,8-PeCDD. The highest fluxes were generally recorded during autumn (Figure 3).

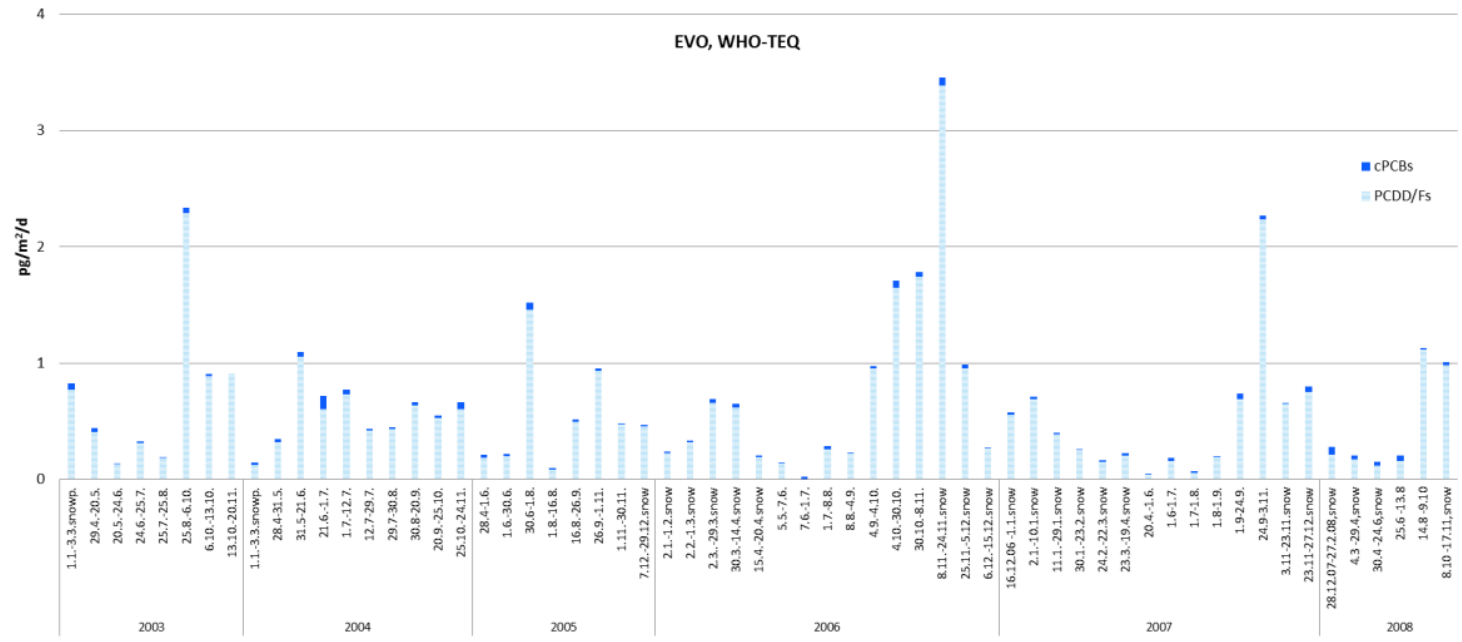

Figure 3. The deposition sample results of PCDD/Fs and $\mathrm{CPCBs}\left(\mathrm{pg} / \mathrm{m}^{2} /\right.$ day) in Evo in years measured the whole year (snowp. = snowprofile and snow = recently fallen snow). 
Table 2. The deposition of PCDD/Fs and cPCBs calculated as WHO-TEQ [34] (pg/m²/day) in some countries, rural (R)/urban (U) (Wallenhorst, Bakogly, Vikelsoe, and Chi I-TEQ).

\begin{tabular}{ccccc}
\hline Location & R/U & PCDD/Fs & cPCBs & References \\
\hline Finland/Utö & $\mathrm{R}$ & $0.1-0.4$ & $<0.1-0.1$ & This study \\
Finland/Evo & $\mathrm{R}$ & $0.3-3.0$ & $<0.1-0.1$ & This study \\
Finland/Pallas & $\mathrm{R}$ & $0.1-0.5$ & $<0.01-0.1$ & This study \\
Sweden & $\mathrm{R}$ & $0.05-0.7$ & & {$[14]$} \\
Sweden & $\mathrm{R}$ & & 0.1 & {$[23]$} \\
Denmark & $\mathrm{U}$ & $2.5-8$ & & {$[25]$} \\
Denmark & $\mathrm{U}$ & $1.2-2.5$ & & {$[24]$} \\
Germany & $\mathrm{R}$ & $3-15$ & & {$[36]$} \\
Germany & $\mathrm{U}$ & $3-20$ & & {$[37]$} \\
United & $\mathrm{R}$ & $3-70$ & & {$[38]$} \\
Kingdom & $\mathrm{U}$ & $20-160$ & & {$[39]$} \\
Italy & $\mathrm{U}$ & & 2.9 & {$[11]$} \\
Italy & $\mathrm{U}$ & $0.75-3.73$ & & {$[40]$} \\
Italy & $\mathrm{R}$ & $<0.01-1.5$ & & {$[35]$} \\
Italy & $\mathrm{U}$ & $21-182$ & & {$[41]$} \\
Turkey & $\mathrm{U}$ & $3-10$ & & {$[42]$} \\
South Korea & $\mathrm{R}$ & $<0.1-43$ & & {$[43]$} \\
Japan & $\mathrm{U}$ & $16-46$ & $0.1-110$ & {$[44]$} \\
Japan & $\mathrm{U}$ & & 1.35 & {$[12]$} \\
Japan & $\mathrm{R}$ & $0.61-3.0$ & & {$[45]$} \\
Taiwan & $\mathrm{R}$ & $0.6-2.6$ & & {$[46]$} \\
United States & $\mathrm{U}$ & 1.5 & & {$[22]$} \\
United States & $\mathrm{R}$ & $0.01-0.15$ & & {$[47]$} \\
Canada & & & &
\end{tabular}

Table 3. Bulk deposition in different years (mean, $\mathrm{SD}=$ standard deviation) of PCDDs, PCDFs, non-ortho PCBs and mono-ortho PCBs WHO-TEQ pg/m²/day in Pallas, Evo, and Utö.

\begin{tabular}{|c|c|c|c|c|c|c|c|c|}
\hline & \multicolumn{2}{|c|}{ PCDDs } & \multicolumn{2}{|c|}{ PCDFs } & \multicolumn{2}{|c|}{ Non-Ortho PCBs } & \multicolumn{2}{|c|}{ Mono-Ortho PCBs } \\
\hline & Mean & SD & Mean & SD & Mean & SD & Mean & SD \\
\hline \multicolumn{9}{|l|}{ Pallas } \\
\hline 2006 & 0.194 & 0.201 & 0.219 & 0.196 & 0.006 & 0.004 & 0.001 & 0 \\
\hline 2007 & 0.068 & 0.107 & 0.105 & 0.141 & 0.03 & 0.029 & 0.001 & 0.001 \\
\hline 2008 & 0.032 & 0.03 & 0.048 & 0.044 & 0.035 & 0.044 & 0.001 & 0 \\
\hline mean & 0.098 & & 0.124 & & 0.024 & & 0.001 & \\
\hline \multicolumn{9}{|l|}{ Evo } \\
\hline 1998 & 0.749 & 0.174 & 0.193 & 0.04 & & & & \\
\hline 1999 & 2.534 & 4.661 & 0.287 & 0.331 & & & & \\
\hline 2000 & 2.718 & 4.007 & 0.235 & 0.216 & 0.064 & 0.015 & & \\
\hline 2001 & 0.292 & 0.158 & 0.091 & 0.08 & 0.038 & 0.016 & & \\
\hline 2002 & 0.221 & 0.105 & 0.103 & 0.099 & 0.031 & 0.018 & & \\
\hline 2003 & 0.479 & 0.656 & 0.126 & 0.119 & 0.025 & 0.02 & & \\
\hline 2004 & 0.339 & 0.177 & 0.185 & 0.093 & 0.026 & 0.02 & 0.001 & 0.002 \\
\hline 2005 & 0.355 & 0.335 & 0.156 & 0.112 & 0.022 & 0.017 & 0.001 & 0.001 \\
\hline 2006 & 0.393 & 0.406 & 0.299 & 0.368 & 0.024 & 0.018 & 0.001 & 0.001 \\
\hline 2007 & 0.233 & 0.198 & 0.18 & 0.281 & 0.015 & 0.011 & 0.001 & 0 \\
\hline 2008 & 0.287 & 0.238 & 0.163 & 0.15 & 0.034 & 0.015 & 0.001 & 0 \\
\hline mean & 0.782 & & 0.183 & & 0.031 & & 0.001 & \\
\hline \multicolumn{9}{|l|}{ Utö } \\
\hline 2002 & 0.273 & 0.285 & 0.248 & 0.32 & 0.029 & 0.017 & & \\
\hline 2003 & 0.095 & 0.092 & 0.087 & 0.101 & 0.011 & 0.011 & & \\
\hline 2004 & 0.087 & 0.061 & 0.044 & 0.045 & 0.01 & 0.009 & & \\
\hline mean & 0.152 & & 0.126 & & 0.017 & & & \\
\hline
\end{tabular}




\section{Discussion}

\subsection{Bulk Deposition Rates}

We measured the highest deposition rates of PCDD/Fs in Evo station; the mean was $1.0 \mathrm{pg} \cdot \mathrm{m}^{-2} \cdot \mathrm{day}^{-1} \mathrm{WHO}-\mathrm{TEQ}$ for the whole period and $0.5 \mathrm{pg} \cdot \mathrm{m}^{-2} \cdot \mathrm{day}^{-1}$ for $2002-2008$, i.e., the timescale comparable with other stations. These were considerably more compared to Utö station in the northern Baltic Proper $\left(0.28 \mathrm{pg} \cdot \mathrm{m}^{-2} \cdot \mathrm{day}^{-1}\right)$ and in Pallas station in northern Finland $\left(0.13 \mathrm{pg} \cdot \mathrm{m}^{-2} \cdot \mathrm{day}^{-1}\right)$. This may indicate a major role of Finnish domestic emissions to the deposition of PCDD/Fs in Evo. The Evo site is situated relatively close to population centers and some $100 \mathrm{~km}$ inland from the Gulf of Finland and the metropolitan area of Helsinki with some 1 million inhabitants, and smaller urban and industrial activity and residual wood and hazardous waste burning is located even closer. About $52 \%$ of the calculated and approximated dioxins emissions in Finland are due to energy production, with traffic, agriculture, and waste management accounting for about 24\%, 19\%, and $5 \%$ of the emissions respectively. The prevailing wind directions from between the south-west (SW) and north (N) during episodes of high deposition (Table 3 and Figure 3) (October 1999, August 2000, October 2003, and November 2006) in Evo further point to domestic sources in this site. At times of low deposition, the prevailing winds were almost from the opposite direction. If PCDD/Fs mostly originated from emissions in Central Europe or Eastern Europe, as suggested in the case of Aspvreten station in Sweden $[14,31,48]$, we would have expected higher or equal concentration and deposition in Utö station than in Evo. However, Utö only showed a higher deposition rate than Evo in 2002, but clearly lower in 2003 and 2004 (Table 3).

Our results on deposition fluxes in Evo are in line but somewhat lower than those measured in rural areas in Sweden [23,31]. In Denmark the PCDD/Fs levels in urban areas have been slightly higher [24,25]. In rural and urban areas in Central Europe and the UK, depositions that were more than 10 times higher were measured, and in southern Europe there were higher depositions of up to two orders of magnitude. Logically, the northernmost station of Pallas exhibited the lowest concentrations and deposition rates for PCDD/Fs, which were in general comparable to those in the arctic environment in Canada $\left(0.01-0.15 \mathrm{pg} \cdot \mathrm{m}^{-2} \cdot\right.$ day $^{-1}$ WHO-TEQ) [47] with only a few exceptions (Table 2). There are few publications that are concerned with the amount of coplanar PCBs in deposition. In Sweden, the amount of coplanar PCBs was at the same level as this study [23], whereas clearly elevated deposition fluxes for dioxin-like PCBs were measured in urban areas in Japan [44].

\subsection{Temporal Trends}

In Evo station, the highest mean deposition rates were measured during the first three years (1998-2000) and were followed by a more or less stable deposition level. Since there were only a few analyses from the winter period before 2002, the mean deposition during this period is probably underestimated. Also in the other stations, with notably lower concentrations and deposition, the highest deposition rates were from the first year of the three years of monitoring. The monthly minimum deposition rates decreased in all stations, as did the maximum deposition rates in Utö and Pallas, with the latter being at very low arctic levels in 2008 (Table 3). Although we only have three years of monitoring from two of the stations, these observations indicate a general and spatially broad decrease in deposition. The temporal trend in deposition in Evo station may be more affected by regional emissions than other stations as discussed earlier.

There were ten significantly $(p$-value $<0.005)$ and five almost significantly $(0.008>p>0.006)$ decreasing trends in different congeners in Evo station (Figure 2). These were mostly highly chlorinated octa-, hepta-, and hexahomologs. Both concentrations and deposition rates were decreasing with congeners 1,2,3,4,7,8-HxCDD, sum HxCDDs, 1,2,3,4,6,7,8-HpCDD, sum HpCDDs, OCDD, 1,2,3,4,6,7,8-HpCDF, and sum HpCDFs. The congener 1,2,3,7,8-PeCDD showed decrease in concentration only. We did not find any significant change in PCDD/PCDF ratio over time, however. A decreasing trend in deposition is expected based on official emission estimates in EMEP countries 
and transport and deposition modelling. The emissions of PCDD/Fs were shown to decline in EMEP countries from 1990 to 2007 by almost 60 percent [8]. Later, however, official emission estimates have been questioned, with Gusev at al. (2011) suggesting that they may have been underestimated by as much as five times. Regardless of uncertainties in emission estimates, our data regarding a general decrease in deposition from the late 1990s to the late 2000s probably reflects a decrease in European and national emissions in general [49].

\subsection{The Gulf of Finland and the Baltic Sea}

The annual deposition rate of PCDD/Fs in Evo varied only slightly, between 0.11 and $0.22 \mathrm{ng} \cdot \mathrm{m}^{-2} \cdot \mathrm{year}^{-1}$ WHO-TEQ in 2002-2008, with data also from winter months and in the corresponding years of other stations. In Utö, deposition rates varied between 0.04 and $0.18 \mathrm{ng} \cdot \mathrm{m}^{-2} \cdot$ year $^{-1}$ and in Pallas between 0.04 and $0.15 \mathrm{ng} \cdot \mathrm{m}^{-2} \cdot$ year $^{-1}$ WHO-TEQ. For cPCBs the annual deposition in Pallas was 2-11 pg.m ${ }^{-2} \cdot \mathrm{year}^{-1}$ WHO-TEQ, in Evo 6-17 pg.m ${ }^{-2} \cdot \mathrm{year}^{-1}$ WHO-TEQ and in Utö 4-8 $\mathrm{pg} \cdot \mathrm{m}^{-2} \cdot \mathrm{year}^{-1}$ WHO-TEQ. Based on official emission estimates, the modelled annual PCDD/F deposition ranged between 0.1 and $0.5 \mathrm{ng} \cdot \mathrm{m}^{-2} \cdot$ year $^{-1}$ TEQ in the Baltic countries and was higher in Central and Eastern Europe in the late 2000s $[8,20]$. The deposition profile of $\mathrm{PCDD} / \mathrm{Fs}$ both in this region and worldwide is dominated by OCDD, followed by $1,2,3,4,6,7,8-\mathrm{HpCDD}, \mathrm{OCDF}$ and 1,2,3,4,6,7,8-HpCDF [22,31,44,50]. While the deposition of dioxins clearly seems to increase with increasing chlorination levels, this is not as obvious with furans [31].

The PCDD/Fs deposition in Utö, c. $0.1 \mathrm{ng} \cdot \mathrm{m}^{-2} \cdot$ year $^{-1} \mathrm{WHO}-\mathrm{TEQ}$, is lower than in Aspvreten, $0.4 \mathrm{ng} \cdot \mathrm{m}^{-2}$. year $^{-1}$ WHO-TEQ [51]. Estimates of atmospheric deposition of PCDD/Fs vary by $30 \%$ due to sampling and pretreatment (elution) methods [32]. The placement, geometry, and other properties of sampling equipment may potentially cause still greater variation. The temporal coverage of sampling, moreover, can play a significant role. In addition to time trends, there are geographical trends [52]. In summary, estimates for the atmospheric deposition of PCDD/Fs in the Baltic Sea area vary by an order of magnitude for reasons that are not clear. Estimates may, to a considerable degree, be related to sampling and measurement methodology in addition to real trends and gradients. In the Bartnicki et al. model output (2009), the atmospheric deposition of PCDD/Fs in the Baltic Sea area varies from 0.1 to $0.2 \mathrm{ng} \cdot \mathrm{m}^{-2}$.year ${ }^{-1}$ WHO-TEQ in Denmark to $<0.03-0.05 \mathrm{ng} \cdot \mathrm{m}^{-2}$.year ${ }^{-1}$ WHO-TEQ in the northern reaches of the Gulf of Bothnia. The MSCE-POP model (Meteorological Synthesizing Centre-East Persistent Organic Pollutants) ([53] pollution data 2002) has calculated the deposition amounts of PCDD/Fs ( $\mu \mathrm{g} \mathrm{I-TEQ} \mathrm{km} \mathrm{km}^{-2}$.year ${ }^{-1}$ ) for the sub-basins of the Baltic Sea. For the Gulf of Finland (GOF) sub-basin, $0.11 \mathrm{ng} \cdot \mathrm{m}^{-2} \cdot$ year $^{-1}$ TEQ was calculated for the deposition flux, which is of the same magnitude as the measured and partially estimated deposition values in Utö. The total deposition for the whole GOF sub-basin area $\left(29,600 \mathrm{~km}^{2}\right)$ in this model calculation was 3.2 I-TEQ $\mathrm{mg} \cdot$ year $^{-1}$ and with the results of Utö 2.7 I-TEQ $\mathrm{mg} \cdot \mathrm{year}^{-1}$, which is quite close to the former figure.

\subsection{Fish}

We considered what kind of impact the PCDD/Fs deposition can have on the possible source of PCDD/Fs in fish. The main dioxin components in fatty fish in the Baltic (e.g., Baltic herring and Baltic salmon) are 2,3,4,7,8-PeCDF and also 1,2,3,7,8-PeCDD, 2,3,7,8-TCDD, and 2,3,7,8-TCDF [54,55]. The Kymi, a river with high levels of PCDD/Fs in sediments, up to $350,000 \mathrm{ng} \cdot \mathrm{kg}^{-1}$ WHO-TEQ $(\mathrm{dw})$, is considered to be the main contributor of dioxins to the GOF. The main component of the Kymi load is the impurity of Ky-5, a wood preservative with mainly 1,2,3,4,6,7,8-HpCDF and lesser amounts of other hexafurans $[56,57]$. The two main congeners in depositions in Utö, calculated as percentage values of WHO-TEQ, were 1,2,3,7,8-PeCDD (about 47\%) and 2,3,4,7,8-PeCDF (about 10\%) (Figure 4). These same congeners dominated in a congener-specific PCDD/Fs emission inventory when calculated, dominating the total TEQ composition [19]. The findings indicate that, regardless of the major importance of the Kymi to the dioxins in the Gulf of Finland, deposition sources may contribute more to the PCDD/Fs intake of fish in the studied sea area. 


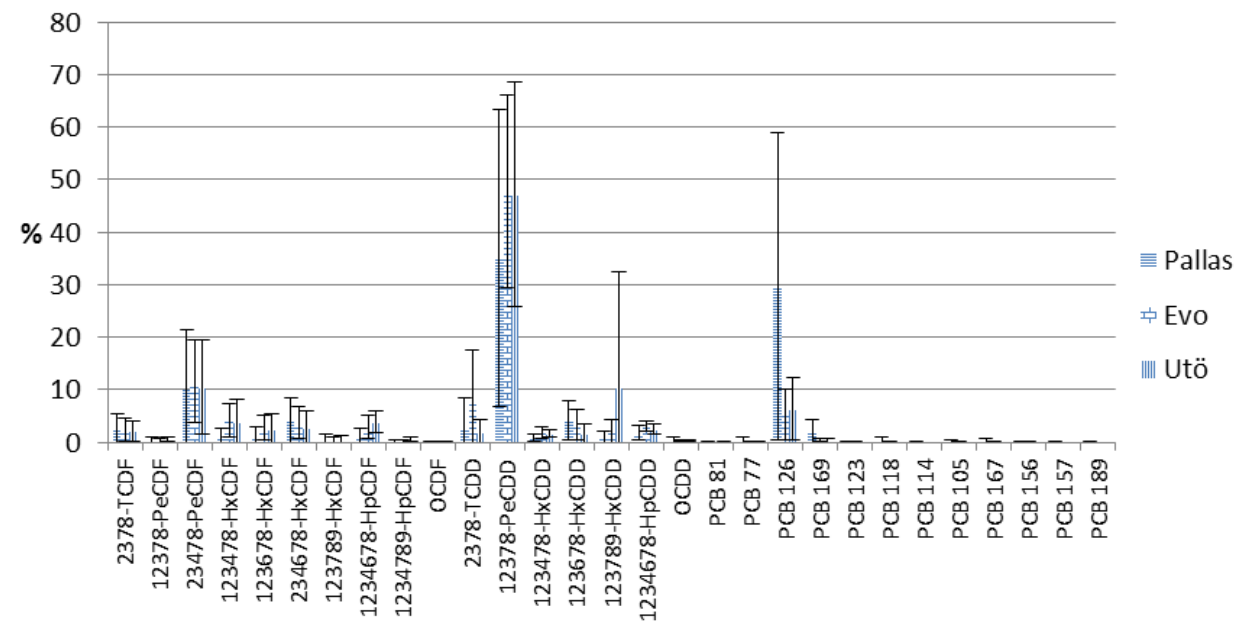

Figure 4. PCDD/Fs and cPCBs congener contributions pg/L WHO-TEQ calculated as \% from the sum of all congeners.

\subsection{PCDD/F Congener Pattern and Congener Contribution to the WHO-TEQ}

Congener patterns of PCDD (toxic congeners included) show increasing concentrations and percentages of the sum of congeners with increasing chlorination levels in all stations (Figure 5). In Pallas, the dioxin homolog OCDD was clearly the most dominant, representing $55 \%$ of all toxic congeners and ranging from $38 \%$ to $42 \%$ in Utö and Evo. A profile with a high relative concentration of OCDD has been considered to be representative for background or environmental sink air samples which have been subjected to different reactions in the air during transport [58,59]. Photolysis of $\mathrm{PCDD} / \mathrm{Fs}$ favors the degradation of the lower chlorinated congeners, resulting in a higher proportion of the higher chlorinated isomers in the air transport masses [60]. The photochemical synthesis of OCDD from pentachlorophenol in condensed water could also be a significant source of OCDD to the environment [5]. Rather similar homolog patterns in the air, except near important local sources, has often been reported [17,61-63], although the individual congeners included in different groups are generally not well-documented.

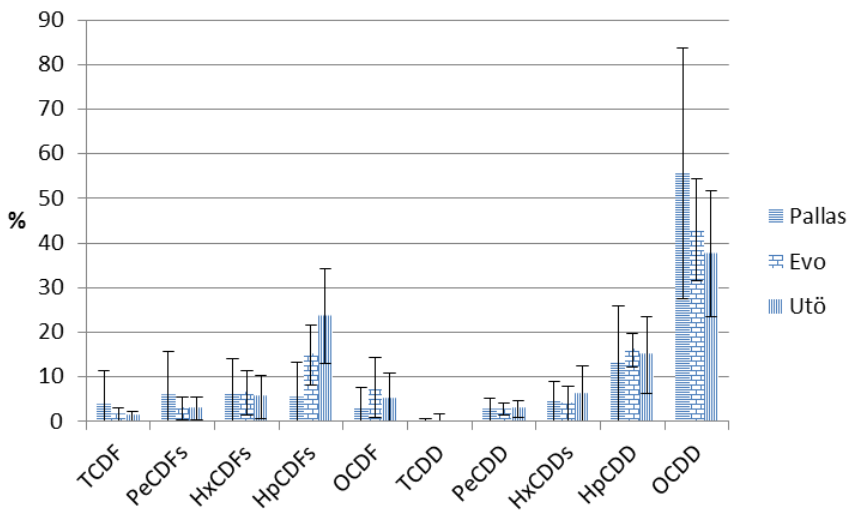

Figure 5. PCDD/Fs (toxic congener) homolog groups pg/L calculated as \% of the sum of all homologs.

On the TEQ basis the pattern is quite different. Congener 1,2,3,7,8-PeCDD dominated in Pallas, Evo, and Utö, being $35 \%, 48 \%$, and $47 \%$ of the overall WHO-TEQ respectively, and followed by 2,3,4,7,8-PeCDF (about 10\%) (Figure 4). The main congeners were the same as in the deposition in the Great Lakes [18]. The same congeners were dominating in deposition flux and air data reported mainly as I-TEQ in different continents, with only the share of congener 2,3,4,7,8-PeCDF being higher than $1,2,3,7,8-\mathrm{PeCDD}$, which could be influenced by the altered TEF factor $[17,61,62,64]$. Tetra- and 
penta-CDD/Fs together account for over $50 \%$ of the total WHO-TEQ. The same kind of results are also reported in literature (usually $>50 \%$ ) [41,63]. In this WHO-TEQ calculation, it should be noted that these congeners are often reported as close as or less than the LOG and then the TEQ is calculated with the assumption that the actual concentration is half the LOG, but in this paper we have calculated this below LOG results with linear regression equations. Using half of the LOG for lighter congeners (especially 2,3,7,8-TCDD) could result in overestimation of their real contribution [17]. The share of 126 PCB was high in Pallas, being 30\% of the total WHO-TEQ, whereas in Evo and Utö it was less than $5 \%$. The amount of 126 PCB calculated in pg/L (Table 1) was at the same level in all areas, while the percentage share of other congeners was bigger in Utö and Evo.

\section{Conclusions}

The findings indicate that, regardless of the major importance of Kymijoki to the dioxins in the Gulf of Finland, deposition sources may contribute more to the PCDD/Fs' intake of fish in the studied sea area. Decreasing temporal PCDD/F deposition trends were observed for highly chlorinated octa-, hepta-, and hexacongeners.

Supplementary Materials: The following are available online at www.mdpi.com/2077-1312/4/3/56/s1.

Acknowledgments: We thank Pekka Vuori from Evo and Ahti Ovaskainen and Eveliina Pääkkölä from Pallas for helping us with the sample collection, and the Finnish Meteorological Institute for providing us with the meteorological data.

Author Contributions: Markku Korhonen: Study planning, sample collection, data handling, data calculations, paper writing, Simo Salo: Data handling, sample collection, Jussi Vuorenmaa: Data calculations, sample collection, Hannu Kiviranta and Päivi Ruokojärvi: Analyses, Matti Verta: Guiding, commenting.

Conflicts of Interest: There are not conflicts of interest.

\section{References}

1. Fujimore, T.; Nakamura, M.; Takaoka, M.; Shiota, K.; Kitajima, Y. Synergetic inhibition of thermochemical formation of chlorinated aromatics by sulfur and nitrogen derived from thiourea: Multielement characterizations. J. Hazard. Mater. 2016, 311, 43-50. [CrossRef] [PubMed]

2. Peng, Y.; Chen, J.; Lu, S.; Huang, J.; Zhang, M.; Buekens, A.; Li, X.; Yan, J. Chlorophenols in municipal solid waste incineration: A review. Chem. Eng. J. 2016, 292, 398-414. [CrossRef]

3. Quass, U.; Ferman, M.; Bröker, G. The European dioxin air emission inventory. Chemosphere 2004, 54, 1319-1327. [CrossRef]

4. Anderson, D.R.; Fisher, R. Sources of dioxins in the United Kingdom: The steel industry and other sources. Chemosphere 2002, 46, 371-381. [CrossRef]

5. Baker, J.J.; Hites, A.R. Is combustion the major source of polychlorinated dibenzo- $p$-dioxins and dibenzofurans to the environment? A mass balance investication. Environ. Sci. Technol. 2000, 34, 2879-2886. [CrossRef]

6. Kulkarni, P.; Crespo, J.; Afonco, C. Dioxins sources and current remediation technologies-A review. Environ. Int. 2008, 34, 139-153. [CrossRef] [PubMed]

7. Wiberg, K.; McLachlan, M.; Jonsson, P.; Johansson, N.; Josefsson, S.; Knekta, E.; Persson, Y.; Sundqvist, K.; Armitage, J.; Broman, D.; et al. Sources, Transport, Reservoirs and Fate of Dioxins, PCBs and HCB in the Baltic Sea Environment; Naturvårdsverket Report 5912; Swedish Environmental Protection Agency: Stockholm, Sweden, 2009.

8. Bartnicki, J.; Gusev, A.; Aas, W.; Valiyaveetil, S. Atmospheric Supply of Nitrogen, Lead, Cadmium, Mercury and Dioxines/Furans to the Baltic Sea in 2007; EMEP Centres Joint Report for HELCOM; Technical Report MSC/W2/2009; Norwegian Meteorological Institute: Oslo, Norway, 2009.

9. Bartnicki, J.; Gusev, A.; Aas, W.; Valiyaveetil, S. Atmospheric Supply of Nitrogen, Lead, Cadmium, Mercury and Dioxines/Furans to the Baltic Sea in 2009; EMEP Centre Joint Report for HELCOM; Technical Report MSC/W2/2011; Norwegian Meteorological Institute: Oslo, Norway; February; 2011.

10. Booth, S.; Hui, J.; Alojado, Z.; Lam, V.; Cheung, W.; Zeller, D.; Steyn, D.; Pauly, D. Global deposition of airborne dioxin. Mar. Pollut. Bull. 2013, 75, 182-186. [CrossRef] [PubMed] 
11. Castro-Jimenez, J.; Mariani, G.; Eisenreich, S.J.; Christoph, E.H.; Hanke, G.; Canuti, E.; Skejo, H.; Umlauf, G. Atmospheric input of POPs into Lake Maggiore (Northern Italy): PCDD/F and dioxin-like PCB profiles and fluxes in the atmosphere and aquatic system. Chemosphere 2008, 73, S122-S130. [CrossRef] [PubMed]

12. Sakai, S.I.; Hayakawa, K.; Takatsuki, H.; Kawakami, I. Dioxin-like PCBs released from waste incineration and their deposition flux. Environ. Sci. Technol. 2001, 35, 3601-3607. [CrossRef]

13. Broman, D.; Näf, C.; Zebuhr, Y. Long-term high- and low-volume air sampling of polychlorinated dibenzo- $p$-dioxines and dibenzofurans and polycyclic aromatic hydrocarbons along a transect from urban to remote aeas on the swedish baltic coast. Environ. Sci. Technol. 1991, 25, 1841-1850. [CrossRef]

14. Sellström, U.; Egeback, A.-L.; McLachlan, M.S. Identifying source regions for the atmospheric input of PCDD/Fs to the Baltic Sea. Atmos. Environ. 2009, 43, 1730-1736. [CrossRef]

15. Gaus, C.; Brunskill, G.J.; Connel, D.W.; Prange, J.; Muller, J.F.; Päpke, O.; Weber, R. Transformation processes, pathways, and possible sources of distinctive polychlorinated dibenzo- $p$-dioxin signatures in sink environments. Environ. Sci. Technol. 2002, 36, 3542-3549. [CrossRef] [PubMed]

16. Oh, E.-J.; Choi, J.; Chang, Y.-S. Gas/particle partitioning of polychlorinated dibenzo-p-dioxins and dibenzofurans in atmosphere; evaluation of predicting models. Atmos. Environ. 2001, 35, 4125-4134. [CrossRef]

17. Lohmann, R.; Jones, K.C. Dioxins and furans in air and deposition: A review of levels, behaviour and processes. Sci. Total Environ. 1998, 219, 53-81. [CrossRef]

18. Zhang, B.; Meng, F.; Shi, C.; Yang, F.; Wen, D.; Aronsson, J.; Gbor, P.K.; Sloan, J.J. Modeling the atmospheric transport and deposition of polychlorinated dibenzo- $p$-dioxins and dibenzofurans in North America. Atmos. Environ. 2009, 43, 2204-2212. [CrossRef]

19. Alcock, R.E.; Sweetman, A.J.; Jones, K.C. A congener-specific PCDD/F emission inventory for the UK: Do current estimates account for the measured atmospheric burden? Chemosphere 2001, 43, 183-194. [CrossRef]

20. Gusev, A.; Rozovskaya, O.; Shalatov, V.; Sokovyh, V.; Aas, W.; Breivik, K. Persistent Organic Pollutants in the Environment. EMEP Status Report 3/2009. Avaliable online: http://www.msceast.org/reports/3_2009.pdf (accessed on 24 August 2016).

21. Vecchiato, M.; Argiriadis, E.; Zambon, S.; Barbante, C.; Toscano, G.; Gambano, A.; Piazza, R. Persistent Ogganic Pollutants (POPs) in Antarctica: Occurrence in contenental and coastal surface snow. Microchem. J. 2015, 119, 75-82. [CrossRef]

22. Correa, O.; Raun, L.; Rifai, H.; Suarez, M.; Holsen, T.; Koenig, L. Depositional flux of polychlorinated dibenzo-p-dioxins and polychlorinated dibenzofurans in an urban setting. Chemosphere 2006, 64, 1550-1561. [CrossRef] [PubMed]

23. Engwall, M.; Brunström, B.; Näf, C.; Hjelm, K. Levels of dioxin-like compounds in sewage sludge determined with a bioassay based on erod induction in chicken embryo liver cultures. Chemosphere 1999, 38, 2327-2343. [CrossRef]

24. Oxbol, A.; Schleicher, O.; Fuglsang, K.; Jensen, A.A.; Borg-Jensen, K.; Schilling, B. Dioxin deposition around a danish municipal incinerator. Organohalog. Compd. 2002, 57, 369-372.

25. Vikelsoe, J.; Hovmand, M.; Andersen, H.V. PCDD/F in deposition, spruce throughfall and air in Denmark. Organohalog. Compd. 2003, 61, 454-457.

26. Korhonen, M.; Kiviranta, A.; Ketola, R. Bulkdeposition of PAHs, PCBs and HCBs in Finland in summer seasons 1993-1996. Toxicol. Environ. Chem. 1998, 66, 37-45. [CrossRef]

27. Chi, K.H.; Liu, K.T.; Chang, S.H.; Chang, M.B. Atmospheric deposition of PCDD/Fs measured via automated and traditional samplers in Northern Taiwan. Chemosphere 2009, 77, 1184-1190. [CrossRef] [PubMed]

28. Guerzoni, S.; Rossini, P.; Sarretta, A.; Raccanelli, S.; Ferrari, G.; Molinaroli, E. POPs in the lagoon of venice: Budgets and pathways. Chemosphere 2007, 67, 1776-1785. [CrossRef] [PubMed]

29. Hortsmann, M.; McLachlan, M.S. Sampling bulk deposition of polychlorinated dibenzo- $p$-dioxins and dibenzofurans. Atmos. Environ. 1997, 31, 2977-2982.

30. Horstmann, M.; McLachnan, M.S. Evidence of novel mechanism of semivolatine organic compound deposition in coniferous forest. Environ. Sci. Technol. 1996, 30, 1794-1796. [CrossRef]

31. McLachlan, M.S.; Sellström, U. Precipitation scavenging of particle-bound contaminants-A case study of PCDD/Fs. Atmos. Environ. 2009, 43, 6084-6090. [CrossRef] 
32. Raccanelli, S.; Guerzoni, S.; Rossini, P.; Favotto, M. Monitoring POPs (PCDD/Fs, PCB, HCB, PAH, DDT) in atmospheric deposition: Sampling and analytical problems. Organohalog. Compd. 2002, 58, 49-52.

33. Kiviranta, A.; Sandell, E.; Hilbert, G.; Poulsen, M.; Brorström-Lunden, E.; Braathen, O.; Oehme, M.; Larsson, P.; Bakke, C.; Ahsbrg, T.; et al. Intercomparison of Sampling Methods for Deposition Measurements of Persistent Organic Compounds; Joint project under the Nordic Council of Ministers, VTT/Kemiantekniikka (VTT.FI); Nordic Council of Ministers: Copenhagen, Denmark, 1993.

34. Van den Berg, M.; Birnbaum, L.S.; Denison, M.; De Vito, M.; Farland, W.; Feeley, M.; Fiedler, H.; Hakansson, H.; Hanberg, A.; Haws, L.; et al. The 2005 world health organization reevaluation of human and mammalian toxic equivalence factors for dioxins and dioxin-like compounds. Toxicol. Sci. 2006, 93, 223-241. [CrossRef] [PubMed]

35. Argiriadis, E.; Rada, E.C.; Vecchiato, M.; Zambon, S.; Ionescu, G.; Schiavon, M.; Ragazzi, M.; Gambaro, A. Assessing the influence of local sources on POPs in atmospheric depositions and sediments near Trento (Italy). Atmos. Environ. 2014, 98, 32-40. [CrossRef]

36. Fiedler, H.; Rappolder, M.; Knetsch, G.; Basler, A. The German dioxin database: PCDD/PCDF concentrations in the environment-Spatial and temporal trends. Organohalog. Compd. 2002, 57, 37-40.

37. Jensen, A.A. Inventories of sources of polychlorodioxins to the Baltic. In Proceedings of the NCM Workshop: Dioxins in Baltic Fish, Helsinki, Finland, 12-13 June 2003.

38. Jones, C.K.; Duarte-Davidson, R. Transfewr of airborne PCDD/Fs to bulk deposition collectors and herbage. Environ. Sci. Technol. 1997, 31, 2937-2943. [CrossRef]

39. Rossini, P.; Guerzoni, S.; Molinaroli, E.; Rampazzo, G.; de Lazzari, A.; Zancanaro, A. Atmospheric bulk deposition to the lagoon of Venice Part I. Fluxes of metals, nutrients and organic contaminants. Environm. Int. 2005, 31, 959-974. [CrossRef] [PubMed]

40. Vassura, I.; Passarini, F.; Ferroni, L.; Bernardi, E.; Morselli, L. PCDD/Fs atmospheric deposition fluxes and soil contamination close to a municipal solid waste inginerator. Chemosphere 2011, 83, 1366-1373. [CrossRef] [PubMed]

41. Bakoglu, M.; Karademir, A.; Durmusoglu, E. Evaluation of PCDD/F levels in ambient air and soils and estimation of deposition rates in Kocaeli, Turkey. Chemosphere 2005, 59, 1373-1385. [CrossRef] [PubMed]

42. Moon, H.-B.; Lee, S.-J.; Choi, H.-G.; Ok, G. Atmospheric deposition of polychlorinated dibenzo- $p$-dioxins (PCDDs) and dibenzofurans (PCDFs) in urban and suburban areas of Korea. Chemosphere 2005, 58, 1525-1534. [CrossRef] [PubMed]

43. Oka, H.; Kakimoto, H.; Miyata, Y.; Yonezawa, Y.; Niikawa, A.; Kyudoh, H.; Kizu, R.; Hayakawa, K. Atmospheric deposition of polychlorinated dibenzo-p-dioxins (PCDDs) and polychlorinated Dibenzofurans (PCDFs) in Kanazawa, Japan. J. Health Sci. 2006, 53, 33-307. [CrossRef]

44. Ogura, I.; Masunaga, S.; Nakanishi, J. Atmospheric deposition of polychlorinated dibenzo-p-dioxins, polychlorinated dibenzofurans, and dioxin-like polychlorinated biphenyls in the Kanto Region, Japan. Chemosphere 2001, 44, 1473-1487. [CrossRef]

45. Chi, K.H.; Luo, S.; Kao, S. J.; Lee, T.Y. Sources and deposition fluxes of PCDD/Fs in a high-mountain lake in central Taivan. Chemosphere 2013, 91, 150-156. [CrossRef] [PubMed]

46. Fiedler, H.; Lau, C.; Cooper, K.; Andersson, R.; Hjelt, M.; Rappe, C.; Bonner, M.; Howell, F. PCDD/PCDF in Atmosphere of Southern Missisippi, USA. Organohalog. Compd. 1997, 33, 122-127.

47. Muir, D.C.G.; de Wit, C.A.; Fisk, A.T. Levels and trends of persistent organic pollutants in the arctic environment. Organohalog. Compd. 2003, 6, 291-294.

48. Shatalov, V.; Johansson, J.H.; Wiberg, K.; Cousins, I.T. Tracing the origin of dioxins in Baltic air using an atmospheric modeling approach. Atmos. Pollut. Res. 2012, 3, 408-416. [CrossRef]

49. Gusev, A.; Dutchak, S.; Rozovskaya, O.; Shatalov, V.; Sokovykh, V.; Vulykh, N. Persistent Organic Pollutants in the Environment. EMEP Status Report 3/2011. Avaliable online: www.msceast.org (accessed on 29 August 2016).

50. Hovmand, M.F.; Vikelsoe, J.; Andersen, H.V. Atmospheric bulk deposition of dioxin and furans to Danish background areas. Atmos. Environ. 2007, 41, 2400-2411. [CrossRef]

51. Armitage, J.M.; McLachlan, M.S.; Wiberg, K.; Jonsson, P. A model assessment of polychlorinated dibenzo-p-dioxin and dibenzofuran sources and fate in the Baltic Sea. Sci. Total Environ. 2009, 407, 3789-3792. [CrossRef] [PubMed] 
52. Assmuth, T.; Jalonen, P. Risks and Management of Dioxin-Like Compounds in Baltic Sea Fish: An Integrated Assesment; Nordic Council of Ministers: Copenhagen, Denmark, 2005; Volume 568.

53. Shatalov, V.; Fedyunin, M.; Mantseva, E.; Strukov, B.; Vulykh, N. Persistent Organic Pollutants in the Environment. EMEP Technical Report, 4/2003. Avaliable online: www.msceast.org (accessed on 29 August 2016).

54. Adams, M. SCALE. Baseline Report on 'Integrated Monitoring of Dioxins and PCBs in the Baltic Region'. Avaliable online: http://ec.europa.eu/environment/archives/health/pdf/dioxins.pdf (accessed on 24 August 2016).

55. Kiviranta, H.; Vartiainen, T.; Parmanne, R.; Hallikainen, A.; Koistinen, J. PCDD/Fs and PCBs in Baltic herring during the 1990s. Chemosphere 2003, 50, 1201-1216. [CrossRef]

56. Salo, S.; Verta, M.; Malve, O.; Korhonen, M.; Lehtoranta, J.; Kiviranta, H.; Isosaari, I.; Ruokojärvi, P.; Koistinen, J.; Vartiainen, T.; et al. Contamination of River Kymijoki sediments with polychlorinated dibenzo- $p$-dioxins, dibenzofurans and mercury and their transport to the Gulf of Finland in the Baltic Sea. Chemosphere 2008, 73, 1675-1683. [CrossRef] [PubMed]

57. Verta, M.; Korhonen, M.; Lehtoranta, J.; Salo, S.; Vartiainen, T.; Kiviranta, H.; Kukkonen, J.; Hämäläinen, H.; Mikkelson, P.; Palm, H. Ecotoxicological and health effects caused by PCP=S, PCDE=S, PCDD=S, and PCDF=S in River Kymijoki Sediments, South-Eastern Finland. Organohalog. Compd. 1999, 43, 239.

58. Tysklind, M.; Fängmark, I.; Marklund, S.; Lindskog, A.; Thaning, L.; Rappe, C. Atmospheric transport and transformation of polychlorinated dibenzo-p-dioxins and dibenzofurans. Environ. Sci. Technol. 1993, 27, 2190-2197. [CrossRef]

59. Wagrowski, D.M.; Hites, R.A. Insights into the global distribution of polychlorinated dibenzo- $p$-dioxins and dibenzofurans. Environ. Sci. Technol. 2000, 34, 2952-2958. [CrossRef]

60. Marklund, S.; Tysklind, M.; Andersson, R.; Ljung, K.; Rappe, C. Environmental deposition of PCDDs and PCDFs as determined by the analysis of Snow Samples from the Northern Sweden. Chemosphere 1991, 23, 1359-1364. [CrossRef]

61. Hippelein, M.; Kaupp, H.; Dörr, G.; McLachlan, M.S.; Hutzinger, O. Baseline contamination assesment for a new resource recovery facility in Germany. Part II: Atmospheric concentrations of PCDD/F. Chemosphere 1996, 32, 1605-1616. [CrossRef]

62. Lohmann, R.; Green, N.J.L.; Jones, K.C. Detailed studies of the factors controlling atmospheric PCDD/F concentrations. Environ. Sci. Technol. 1999, 33, 4440-4447. [CrossRef]

63. Moon, H.B.; Lee, S.J.; Choi, H.G.; Kim, S.S.; Choi, M.K.; Lee, P.Y.; Ok, G. Atmospheric deposition of PCDDs, PCDFs and dioxin-like PCBs from urban and suburban areas of Korea. Organohalog. Compd. 2003, 61, 450-457.

64. Shih, M.; Lee, W.-S.; Chang-Chien, G.-P.; Wang, L.-C.; Hung, C.-Y.; Lin, K.-C. Dry deposition of polychlorinated dibenzo-p-dioxins and dibenzofurans (PCDD/Fs) in ambient air. Chemosphere 2006, 62, 411-416. [CrossRef] [PubMed]

(C) 2016 by the authors; licensee MDPI, Basel, Switzerland. This article is an open access article distributed under the terms and conditions of the Creative Commons Attribution (CC-BY) license (http://creativecommons.org/licenses/by/4.0/). 